\title{
IEOOS: the Spanish Institute of Oceanography Observing System
}

\author{
Elena Tel $^{1}$, Rosa Balbin ${ }^{2}$, Jose-Manuel Cabanas ${ }^{3}$, Maria-Jesus Garcia ${ }^{1}$, M. Carmen Garcia-Martinez ${ }^{4}$, \\ Cesar Gonzalez-Pola ${ }^{5}$, Alicia Lavin ${ }^{6}$, Jose-Luis Lopez-Jurado ${ }^{2}$, Carmen Rodriguez ${ }^{6}$, Manuel Ruiz-Villarreal ${ }^{7}$, \\ Ricardo F. Sánchez-Leal ${ }^{8}$, Manuel Vargas-Yáñez ${ }^{4}$, and Pedro Vélez-Belchî ${ }^{9}$ \\ ${ }^{1}$ Instituto Español de Oceanografía, Servicios Centrales, Madrid, Spain \\ ${ }^{2}$ Instituto Español de Oceanografía, Centro Oceanográfico de Baleares, Palma de Mallorca, Spain \\ ${ }^{3}$ Instituto Español de Oceanografía, Centro Oceanográfico de Vigo, Vigo, Spain \\ ${ }^{4}$ Instituto Español de Oceanografía, Centro Oceanográfico de Fuengirola, Fuengirola, Spain \\ ${ }^{5}$ Instituto Español de Oceanografía, Centro Oceanográfico de Gijón, Gijón, Spain \\ ${ }^{6}$ Instituto Español de Oceanografía, Centro Oceanográfico de Santander, Santander, Spain \\ ${ }^{7}$ Instituto Español de Oceanografía, Centro Oceanográfico de A Coruña, A Coruña, Spain \\ ${ }^{8}$ Instituto Español de Oceanografía, Centro Oceanográfico de Cádiz, Cádiz Spain \\ ${ }^{9}$ Instituto Español de Oceanografía, Centro Oceanográfico de Canarias, Santa Cruz de Tenerife, Spain
}

Correspondence to: E. Tel (elena.tel@md.ieo.es)

Received: 31 July 2015 - Published in Ocean Sci. Discuss.: 27 October 2015

Revised: 2 February 2016 - Accepted: 11 February 2016 - Published: 4 March 2016

\begin{abstract}
Since its foundation, 100 years ago, the Spanish Institute of Oceanography (IEO) has been observing and measuring the ocean characteristics. Here is a summary of the initiatives of the IEO in the field of the operational oceanography. Some systems like the tide gauges network has been working for more than 70 years. The standard sections began at different moments depending on the local projects, and nowadays there are more than 180 coastal stations and deep-sea ones that are systematically sampled, obtaining physical and biochemical measurements. At this moment, the Observing System includes six permanent moorings equipped with current meters, an opensea ocean-meteorological buoy offshore Santander and a sea-surface temperature satellite image station. It also supports the Spanish contribution to the Argo international programme with 47 deployed profilers, and continuous monitoring thermosalinometers, meteorological stations and vesselmounted acoustic Doppler current profilers on the research vessel fleet. The system is completed with the contribution to the Northwest Iberian peninsula and Gibraltar observatories, and the development of regional prediction models. All these systematic measurements allow the IEO to give responses to ocean research activities, official agencies requirements and industrial and main society demands such as navigation, resource management, risks management, recreation, as well as
\end{abstract}

for management development pollution-related economic activities or marine ecosystems. All these networks are linked to international initiatives, framed largely in supranational programmes of Earth observation sponsored by the United Nations or the European Union. The synchronic observation system permits a spatio-temporal description of some events, such as new deep water formation in the Mediterranean Sea and the injection of heat to intermediate waters in the Bay of Biscay after some colder northern storms in winter 2005.

\section{Introduction}

Operational oceanography $(\mathrm{OO})$ is the activity of systematic and long-term routine measurements of the seas and oceans, their interpretation and dissemination (Parrilla, 2001) in order to fulfil upcoming needs from many different sectors: industry, service, policy making, etc., besides the scientific one. The IEO's goal is scientific knowledge of the oceans and the marine environment and has been developed based on observation and research. For more than 2 decades it has been investing resources, time and funds in the field of $\mathrm{OO}$, to promote results for social development and benefit. Institutional strengthening is desirable for the network of sampling it has developed. The results are given to the interested national and 
international community and the IEO's Spanish representative in the European forums (International Oceanographic Data and Information Exchange (IODE), International Council for the Exploration of the Sea (ICES), ...) for appropriate action. Some data collected across this Observing System are linked to international initiatives. As an example, the IEO participates in the Fixed-point Open Ocean Observatory network (FixO3) European project with data from the Augusto Gonzalez de Linares (AGL) buoy; and nutrients and dissolved oxygen information from water samples at different depth levels, that are collected along the hydrographic sections, are included in the European Marine Observation and Data Network (EMODNet, DG-Mare/2012) initiative in order to improve the knowledge and construct distribution maps of the variables along the European coasts.

An increase in ocean measurements and the availability of information on sea behaviour and variability provide a fundamental opportunity for the rational use and exploitation of the ocean. This is an important factor for Blue Growth and a green economy. In a sense, the more ocean data we can collect, the better responses to the social demands we will be able to offer, such as for improved weather forecasts, searelated hazard prevention, marine safety and coastal tourism.

Although all the data sets are quality controlled locally by the researchers that are responsible for the different programmes, the IEO performs a double validation when the data arrive to its data centre for permanent archiving. Following the internationally agreed protocols, data are checked for spikes and position/date errors, and validated against climatological values in the different areas. To preserve the data for the future, all detected problems are flagged with a numerical code, that gives added value to the original data and facilitate further use of them. Reformatted to internationally accepted standard formats, and meta-dated following the Pan-European Infrastructure for Ocean and Marine Data Management (SeaDataNet) protocols and the INSPIRE directive (2007/2/EC), both, data and metadata, are incorporated into the IEO data archive structure, linked to the SeaDataNet network, and made accessible through the web portal www.seadatanet.org.

This paper aims to give a general overview of the different programmes that the IEO supports to achieve its scientific objectives as well as to serve the different demands that are imposed by the society. The different programmes evolve as time passes, adapting new technologies and sampling strategies to fulfil IEO needs and the ability to manage them.

\section{Tide gauge network}

The Spanish tide gauge network (Red Operacional de NIvel del MAR, RONIMAR) has been operating since 1943. It has 12 stations, four of them on islands, conforming to international requirements and contributing with the data to the Permanent Service for Mean Sea Level (PSMSL). Some stations are integrated into the Global Sea Level Observing System (GLOSS) and the long period of data registered by RONIMAR has made it possible to integrate these sea level time series to global and regional data sets for studies of longterm trends, as well as for decadal and interannual variability (Tel and Garcia, 2002; Tel, 2007). Nowadays the sea level is sampled every $5 \mathrm{~min}$ in most of the stations and these data are also relevant for the estimation of extreme sea levels (Garcia et al., 2012). Over time, the tide gauge network has been upgraded in line with technological advances, both in terms of system measurement (from the mechanical tide gauge with graphical recorder to a radar technology) and in relation to data transmission (from postal mailing to automatic transmission). Nowadays, four stations (Palma de Mallorca, Vigo, Cádiz, and Puerto de la Luz) are sampled every minute, and can be used in seiche or tsunami studies. These tide gauge data are made available daily at http://indamar.ieo.es.

\section{Hydrographic monitoring sections}

The IEO has been monitoring the Spanish shelf waters for the last 25 years. This is the oldest national field programme for multidisciplinary marine research addressing long-term variability issues at ecosystem level (Bode et al., 2014). Core observations include ship-based hydrographical, biogeochemical and plankton observations at monthly frequency in several oceanographic sections along the Iberian shelf. The first series was initiated in the northwestern shelf (Valdes et al., 2002), and other programmes extended the observations to the Mediterranean in 1992 (López-Jurado et al., 2015). This long-term monitoring gives knowledge about differences in the large-scale off-shore oceanographic conditions along the water column (Vargas-Yáñez et al., 2012), and description of the intermediate water seasonal formation (Vargas-Yáñez et al., 2010).

In 2003, an initiative (RadProf) to semiannually sample off-shelf waters using the same approach was established in order to understand the mechanisms governing the internal variability of the ocean, and therefore of the climate. The Finisterre section takes a good representation of the Eastern Boundary Waters along the Iberian Basin and western Galician Bank. In 2006 the deep hydrographic section around the Canary Islands began, in order to establish the scales of variability in the decadal/subdecadal range in the subtropical gyre, specifically in its eastern margin (Velez-Belchi et al., 2014). In 2009, new stations in the Gulf of Cádiz (STOCA programme) were added to the network (Monteiro et al., 2015). The results of water sample analysis at the different levels are included in the EMODNet (chemistry) network. The Details of the network are summarized in Fig. 1 and Table 1 .

With the data collected, the IEO is able to detect deep changes produced in the Bay of Biscay and Mediterranean Sea. As an example, the extremely cold and dry winter of 
Table 1. Summary of the different hydrographical sections programmes carried out by the IEO and their contributions to international initiatives.

\begin{tabular}{|c|c|c|c|c|}
\hline Programme & Start year & No. & Geographical area & $\begin{array}{l}\text { Contributing } \\
\text { programmes }\end{array}$ \\
\hline Radiales & 1990 & 16 & Cantabrian Sea and NW Coast & EmodNet \\
\hline RadMed & 1992 & 85 & $\begin{array}{l}\text { Western Mediterranean, Alborán } \\
\text { Sea, Balearic islands }\end{array}$ & $\begin{array}{l}\text { EmodNet, } \\
\text { MonGOOS }\end{array}$ \\
\hline RadProf & 2003 & 24 & NW Iberian Basin, Galician Bank & $\begin{array}{l}\text { EmodNet, } \\
\text { ICES/WGOH }\end{array}$ \\
\hline RaProCan & 2006 & 50 & Canarian Basin & EmodNet \\
\hline STOCA & 2009 & 16 & Gulf of Cádiz & EmodNet \\
\hline
\end{tabular}

MonGOOS: Mediterranean Operational Network for the Global Observing System is part of EuroGOOS. ICES/WGOH: ICES Working Group on Oceanic Oceanography.

2005 in southwestern Europe was detected based on the different character of the water masses. In the southern Bay of Biscay, information from the IEO Shelf and Slope sections shows that in the Bay of Biscay the episode caused a profound transformation of the upper ocean hydrographical structure, making it completely different to what it was in the previous decade (Somavilla et al., 2009). The strong local cooling and the precipitation deficit resulted in the highest density flux estimated, which triggered the mixed layer to reach unprecedented depths, affecting directly the East North Atlantic Central Water (ENACW) that is usually unconnected to air-sea interaction. In the western Mediterranean the anomalous low precipitation and persistency of northerlies over the NW Mediterranean caused a large extension both in time and space of deep convection processes (LopezJurado et al., 2005) and a New Western Mediterranean Deep Water (N-WMDW) was produced, slightly denser, warmer and saltier than the usual WMDW (Salat et al., 2007). Also near the continental slope, a cascading of colder and even denser water was found (Puig et al., 2013), affecting biological processes over the whole water column (e.g. Company et al., 2008; Rodríguez et al., 2013; Carbonell et al., 2014; Hidalgo et al., 2014). In the last years, linked to the growing interest in Mediterranean Sea health state, new variables ( $\mathrm{pH}$, Total Inorganic Carbon, $\mathrm{NO}_{2}, \mathrm{CH}_{4}$ ) have been added to the original sampling (Amengual et al., 2010). This multidisciplinary approach allows improved management of shortlifecycle species such as Octopus vulgaris (Vargas-Yanez et al., 2009). All the RadMed oceanographic stations are included in the Mediterranean Operational Network for the Global Observing System (MonGOOS) and in the IBAMar database (Aparicio et al., 2015).

Along the Iberian Basin and NW slope, seasonality signals in the vein of Mediterranean Water have been detected in the area, with the vein constrained to the shelf break in the summer and widely distributed in winter (Prieto et al., 2013). Complete deep section coverage in the Cantabrian Sea has been discontinued recently although some deep stations have been included for monthly sampling. The aim is

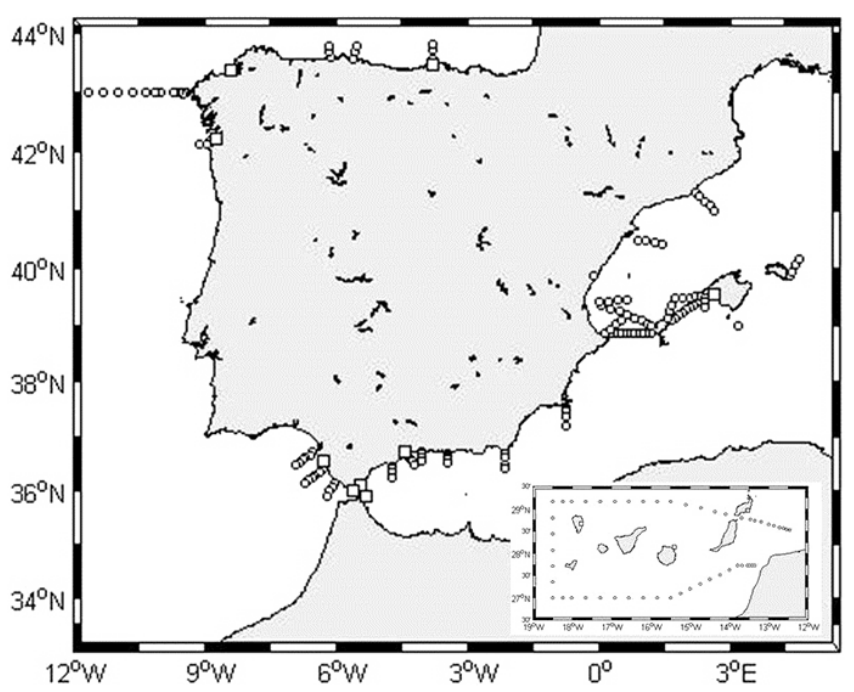

Figure 1. IEO tide gauge network (squares) and oceanographic stations (dots) from the IEO hydrographic monitoring sections. AGL buoy is close to the most external station of the Santander hydrographic section.

to establish the scale of variability in the decadal/subdecadal range. Its information contributes to the knowledge of the oceanographic climatic variability and global change monitoring (Prieto et al., 2015).

The Canary Islands are immersed in the eastern margin of the North Atlantic subtropical gyre, in the coastal transition zone of the Canary Current Upwelling System. The warming of the upper $600 \mathrm{~m}$ continues at a rate of $0.14{ }^{\circ} \mathrm{C}$ decade $^{-1}$ in the oceanic waters and $0.32{ }^{\circ} \mathrm{Cdecade}^{-1}$ in the waters between Lanzarote and Africa under the influence of upwelling off the African coast. At intermediate levels the warming continues at a rate of $0.04{ }^{\circ} \mathrm{Cdecade}^{-1}$ in the oceanic waters and $0.08^{\circ} \mathrm{Cdecade}^{-1}$ in the waters between Lanzarote and Africa. At deeper levels, since 1997 there is no statistically significant trend. Regarding the oceanic circulation, the Canary Current presents a seasonal cycle, with the minimum 
transport occurring during the autumn, concentrated between Tenerife and Lanzarote Islands (Vélez-Belchí et al., 2010).

\section{Permanent moorings}

In the Atlantic Ocean, the IEOOS has had two deep moorings in the RadProf monitoring of N/NW Iberia since 2004: Finisterre and Santander. The second stopped in September 2010 but in August 2010 a new mooring was established in Asturias $\left(44^{\circ} 03^{\prime} \mathrm{N}, 005^{\circ} 53^{\prime} \mathrm{W}\right)$. Mooring lines, equipped with current meters at the cores of main water masses, have been operative with some interruptions since 2003 at the western Iberian margin and in southern Biscay, and complete the hydrographic sections' sampling. The goal is to maintain at least one mooring line in each region. In the Canary Basin a permanent mooring has been placed in the Eastern Boundary Current (EBC) to quantify the water mass variability of currents, including the Canary Current (Velez-Belchi et al., 2015).

In the Gibraltar Strait, the IEO is involved in the Gibraltar monitoring system with a mooring that began in the framework of the national research project "Water exchanges through the Strait of Gibraltar and their response to meteorological and climate forcing (INGRES)" in collaboration with the University of Málaga. In the Mediterranean Sea, the HYDROCHANGES programme (Schroeder et al., 2013) comprises an international set of deep moorings for the longterm monitoring of hydrological variability. The IEOOS contributes to this programme with a mooring on the continental slope north of the Ibiza Channel and another NE of Menorca Island. The moorings maintenance is planned to be every 6 to 12 months within the RadMed monitoring programme (Lopez-Jurado et al., 2005).

\section{Ocean-meteorological buoy}

Deployed in 2007 , at $43^{\circ} 50^{\prime} \mathrm{N}, 3^{\circ} 47^{\prime} \mathrm{W}$, the Augusto Gonzalez de Linares (AGL) buoy is located $22 \mathrm{nmi}$ (nautical miles) north of Cape Mayor, off Santander (southern Bay of Biscay). Water depth at the buoy site is $2850 \mathrm{~m}$. It is equipped with meteorological sensors for air temperature, atmospheric pressure, air humidity and wind (velocity and direction), and ocean sensors for waves (height and direction), subsurface seawater temperature and salinity, chlorophyll-A concentration and dissolved oxygen. Finally, a $300 \mathrm{kHz}$ Doppler current profiler monitors the first $100 \mathrm{~m}$ horizontal currents.

The obtained information is of great importance for scientific, meteorological, environmental, fishery, maritime and tourist activities which thus have a realtime marine information source. Integration of different scales has been a matter of study from hourly to monthly, and some products are freely available, together AGL buoy realtime data, at www.boya_agl.st.ieo.es. Delayed-time data from 2007 to 2014 are also available through www.seadatanet.org. As an
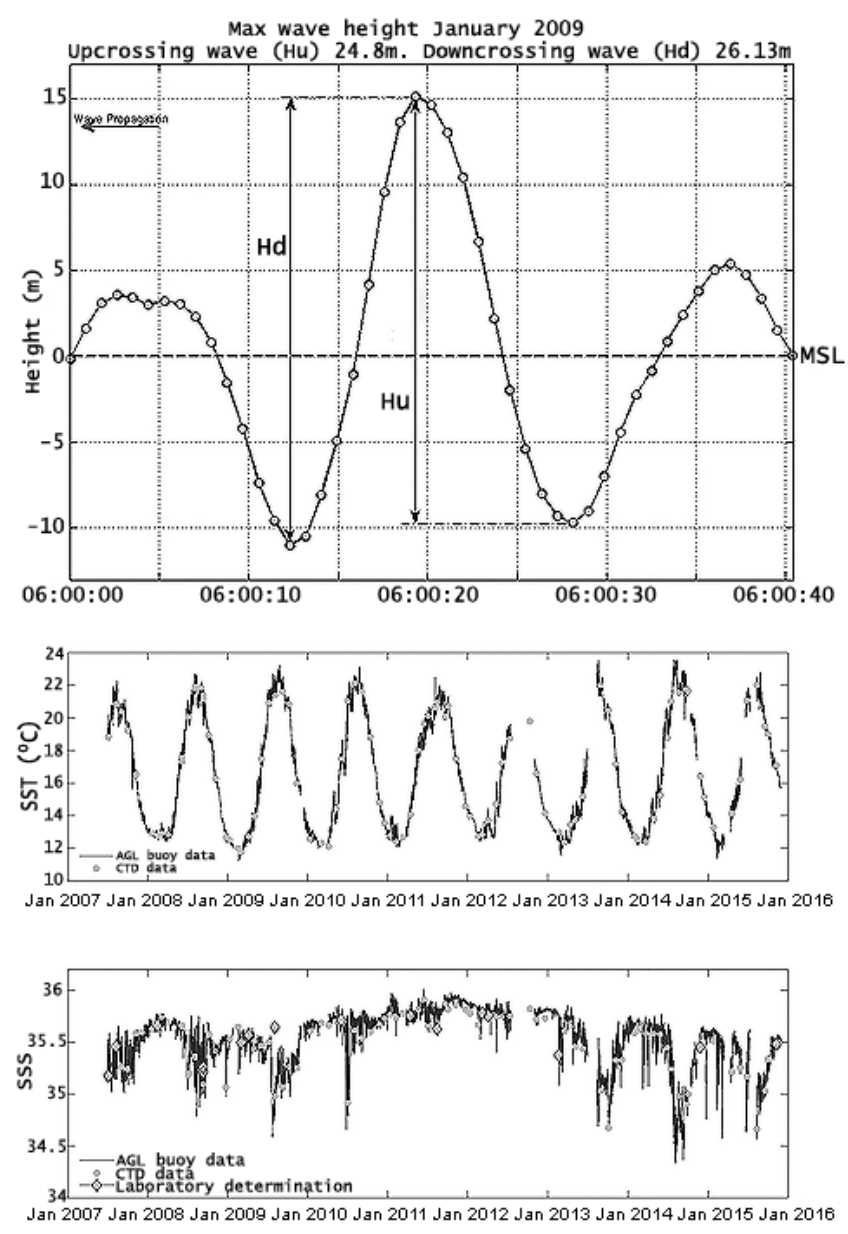

Figure 2. Big wave recorded by the AGL buoy (above) and time series (below) for continuous temperature and salinity recorded at the buoy, and data obtained by systematic CTD and water bottle samples taken at the Santander hydrographic section.

example, Fig. 2 shows the $26 \mathrm{~m}$ height wave recorded in the Cantabrian Sea during a big storm in winter 2009, and the time series for salinity and water temperature. These are monthly validated against CTD and water bottles that are systematically taken at the Santander hydrographic section.

The Biscay AGL buoy is the IEOOS contribution to the FixO3 European project.

\section{IEO Research vessels underway monitoring}

Nowadays the IEO maintains continuously working five thermosalinometers (TSG), four meteorological stations, four marine data management systems and two vessel-mounted ADCP on board the IEO R/V fleet. Collected data are routinely sent to the IEO data centre for quality control (mainly date, position and range for near-realtime data), dissemination and archiving. 
An automatic data processing system was developed to manage all the information generated in quasi-real time by this surface sampling network. The developed software applies standard systematic control subroutines and prepares the data to save them into local databases and generate preliminary graphical outputs. All network data are stored in a Thematic Realtime Environmental Distributed Data Services server (THREDDS) to facilitate access by the scientific community and its visualization by means of Open Geospatial Consortium (OGC) standard services. Nowadays an automatic data storage system based on a PostgresSQL/PostGIS database is being developed in order to make easy the implementation of a user-friendly web service to visualize and download this kind of data.

These systematic measures have allowed some climatological products based on repeated measurements. So, from thermosalinometer data, the monthly sampling survey from Santander to Gijón, has enabled subsurface temperature and salinity maps of the Cantabrian Sea (Viloria et al., 2012; Viloria, 2012) and allowed us to arrive at a better description of coastal conditions and their seasonal variability. In Galician rias where the inter-seasonal variations have consequences such as algae blooms that strongly affect local fisheries, the weekly repeated surveys (see Fig. 3 showing the four tracks in December 2015) of R/V Navaz since 2008 allows us to arrive at better description of the variability patterns (Tel et al., 2014).

\section{IEO contribution to Argo international programme}

Spain has participated in the international Argo programme since its beginning (Roemmich et al., 2009; Freeland et al., 2010). This participation began in 2002 through the first European project when a total of 80 Argo profilers were deployed in the North Atlantic. Since then, the IEO has led different special governmental actions through which the ArgoSpain programme is being financed. At this moment a total of 47 profilers has been deployed since 2003, and nine are active. Additionally, 10 profilers were acquired for three Spanish research groups as part of their observational strategy. Currently, continued Spanish participation in the Argo programme is awaiting official confirmation to adherence to the recently created European research infrastructure Euro-Argo. Nowadays, the Spanish contribution to Argo is a join venture between the IEO and the Balearic Island Coastal Observing and Forecasting System (SOCIB) (Tintore et al., 2013).

The Spanish participation has always been subject to scientific objectives, whether to support independent objectives approved under the $\mathrm{R}+\mathrm{D}$ National Plan or as a means to achieve the goals of the Argo-Spain programme. These objectives are the study of the mass transport variability and the changes in temperature and salinity in the North Atlantic $\left(24.5^{\circ} \mathrm{N}\right)$ (Vélez-Belchí et al., 2010), and the Meridional

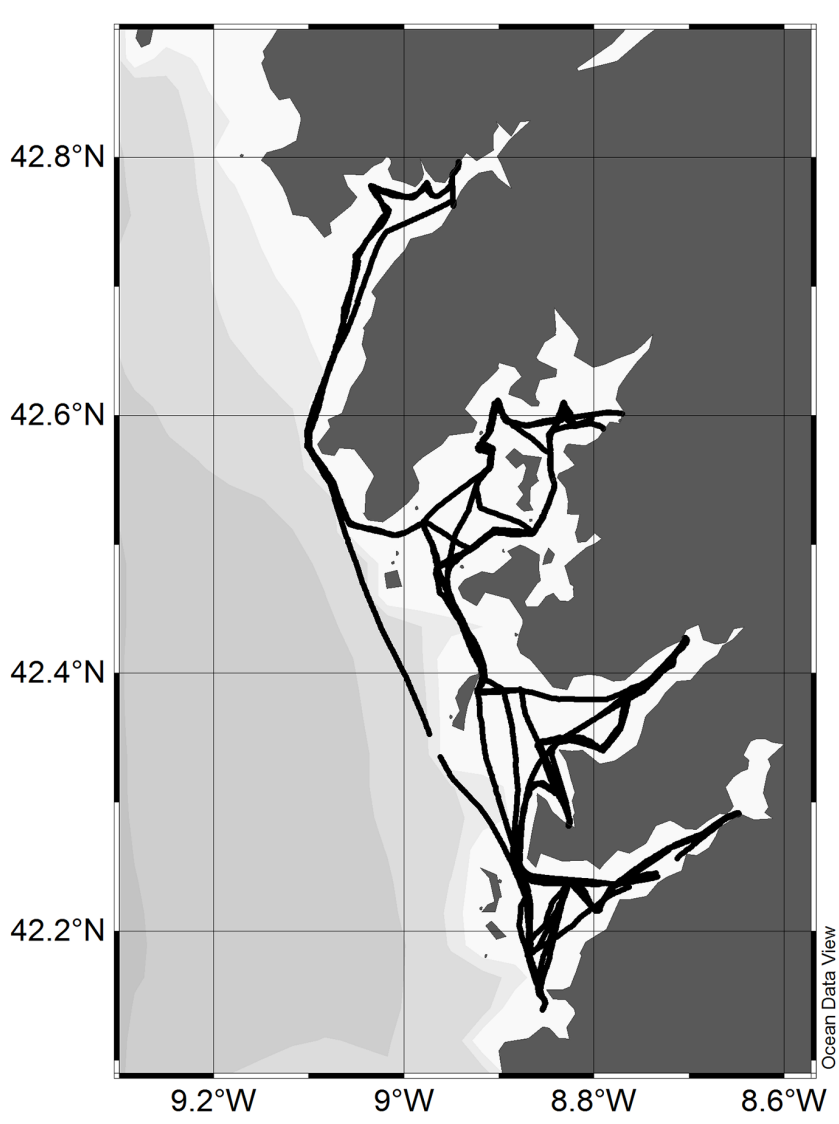

Figure 3. Weekly repeated tracks of the R/V Navaz during December 2015.

Overturning Circulation in the North Atlantic (HernandezGuerra et al., 2010).

\section{Satellite SST images reception station}

In July 1998 a satellite data reception station was mounted at the IEO Santander Centre. From 1998 to 2007 the station acquired and stored important information for different studies of ocean trends. Because of technical problems the station stopped working in 2007, but a new reception station was mounted in 2010 . The system receives, archives, processes and displays data from NOAA and Metop satellites. From these data, sea surface temperature (SST) images are obtained for five different geographical areas and distributed in near-realtime on the IEO website. These SST images are in JPEG format with a suitable colour palette applied. Nowadays, 10 daily SST images are available on the website and SST data will soon be available in a standard distribution format for satellite images.

The main scientific objectives are related to the identification of mesoscale features, as coastal marine ecosystems and continental margins represent the transition zone between the continents and ocean basins, and they play a crucial role 
in regulating the materials and energy exchanges between mainland and the deep ocean (Otero et al., 2009), being areas of intense biological productivity. In particular, these data have also been used in studies of the oceanographic conditions following the Prestige oil spill accident (Ruiz-Villarreal et al., 2006). Furthermore, assimilation of satellite data is an important tool for the validation of the hydrographical circulation models of the area and an important support tool (Garcia-Soto, 2004) for the design and development of Spanish oceanographic surveys and research.

\section{Hydrodynamical forecasting models}

The IEO runs high-resolution models in the N-NW Iberian Peninsula simulate oceanographic water conditions and their variability in response to wind events (Otero et al., 2008) as well as the oceanographic conditions during harmful algal blooms (HABs). The main task consists of providing insight into the coastal and ocean dynamics in support to the intense IEO ecosystem and fisheries research in the area. The Regional Ocean Model System (ROMS) outputs for temperature, salinity and currents are freely available through a THREDDS server http://centolo.co.ieo.es:8080/thredds/ catalog/ROMS-IEO/catalog.html. In a data viewer http: //www.indicedeafloramiento.ieo.es/index1_en.php, the following products derived from ROMS model output are generated: thermal, haline and mix layer fronts, eddies, shellfishing harvesting areas and temperature at beaches.

In recent years, a high-resolution $(\sim 3 \mathrm{~km})$ configuration of the ROMS physical model with realistic atmospheric forcing, which has been shown to represent the main features of the shelf and slope circulation in the area, was run coupled to a biogeochemical model (N2PZD2). Any biogeochemical model aimed at providing a reliable representation of the dynamics of a certain area should be tuned according to the area characteristics. In an upwelling system, the composition of phytoplankton varies from the beginning to the end of the bloom. The spring bloom is reasonably reproduced in the NW and N coasts in time, space and intensity (Garcia-Garcia et al., 2016). Some examples of the use of the IEO models are to get some insight into sardine recruitment variability and harmful algal bloom prediction (Ruiz-Villarreal et al., 2016). In the last case, the circulation models of rias, data from the RV Navaz thermosalinometer and CTD monthly profiles from the Radiales programme at Ria de Vigo, have enabled an HAB alert process http://www.asimuth.eu/en-ie/ HAB-Bulletin/Pages/default.aspx that is used by fishermen and local aquiculture enterprises in order to manage their activities.

\section{Conclusions}

The Spanish Institute of Oceanography (IEO) maintains a large and coherent ocean observing system around the
Iberian Peninsula, the Canary and the Balearic islands. The Spanish Institute of Oceanography Observing System (IEOOS) provides quality-controlled data and information about Spanish surrounding waters and comprehends several subsystems. Furthermore, all the information obtained from the IEOOS is valuable for the study of the biological resources and their dependence on the physico-chemical variables (Alemany et al., 2010, e.g.), and also physical effects like the formation of deep and intermediate water masses (Somavilla et al., 2013; Vargas-Yáñez et al., 2012, e.g.), modification and transport (Lopez-Jurado et al., 2005, e.g.), and oscillations and trends in environmental variables (Prieto et al., 2015; Vargas-Yáñez et al., 2010), while modelling information is successfully used by local fisheries.

The success of the hydrographical sections extends beyond pure scientific knowledge, as the expertise gathered with the programme has been applied to solve multiple environmental issues, from fisheries and pollution to global change. The Marine Strategy Framework Directive (MSFD), whose main objective is the achievement of good environmental status of European seas, is planning marine environment action policy. The IEO is already conducting many of the required evaluations on the Spanish coasts. In fact, data collected in the framework of the IEOOS structure has been the core of the initial assessment and the key element for the identification of environmental objectives that follow.

The new IEO research vessels are well-equipped automatic systems that enormously increase the capacity of sampling the ocean along the ship tracks, and a collaboration with the national forecast services is expected in the near future in order to provide them data in near-realtime.

In the pursuit of giving visibility to the sampling network IEO data, as well as the activities of this group, a single web portal style is currently being developed. This will help to strengthen position and status within the national and international framework as well as responding to demands under recent proposals such as Emodnet initiatives, the EU Framework Programme for Research and Innovation: Horizon 2020, and MSFD. In this sense, the IEO is currently devoting a strong effort to give visibility to all the data obtained in the framework of its OO programmes, incorporating them into structures as SeaDataNet or EmodNet, developing webbased viewers and maintaining permanent servers and services. This effort will result in a better reuse of data and information obtained and benefit a wide community of final users.

Acknowledgements. The authors wish to express their deepest gratitude to the IEO people, researchers and technicians, who have made their assistance for the success of this observing system. Special thanks must be given to Daniel Cano and Agueda Cabrero for their patience and support for the figures that are included in this paper.

The monitoring programme of the IEO, the IEOOS is mainly funded by the Instituto Español de Oceanografía, but some compo- 
nents have been occasionally funded by ESEAS-RI (EVR1-200100042), VACLAN (PN I+D+I REM2003-08193-CO3-007MAR), COVACLAN (PN I+D+I CTM2007-646007MAR), RAIA (Interreg POCTEP/2012-2015/0520-RAIA-CO-1E and Interreg IV/20092011/0313-RAIA-1E), FixO3 (FP7-INFRA-2012-1.1.11/312463), INGRES3 (PN I+D+I, CTM2010-21229-C02), DESMOND (PN I+D+I CTM2008-05695-C02-01) PERSEUS (FP7-287600) and the IRIS-SES (FP7-07.0335/2013/659540/SUB/C2), FEDER funds for the satellite SST images reception station (IEOC084E-017), Argo special actions (REN2001-4022-E, CAC2007-02, ICTS2008-14 and ACI2009-998), SeaDataNet (FP6/20022006/026212), SeaDataNetII(FP7/2007-2013/283607), FixO3 (FP7/2007-2013/312463), ASIMUTH (FP7 SPACE.2010.1.1-01 Grant Agreement 261860).

Edited by: A. Crise

\section{References}

Alemany, F., Quintanilla, L., Velez-Belchi, P., Garcia, A., Cortes, D., Rodriguez, J., de Puelles, M. F., Gonzalez-Pola, C., and Lopez-Jurado, J.: Characterization of the spawning habitat of Atlantic bluefin tuna and related species in the Balearic Sea (western Mediterranean), cLimate Impacts on Oceanic TOp Predators (CLIOTOP) International Symposium, Prog. Oceanogr., 86, 21-38, doi:10.1016/j.pocean.2010.04.014, 2010.

Amengual, T., Aparicio, A., Balbín, R., De Puelles, M. F., GarcíaMartínez, M., Gaza, M., Jansá, J., Lopez-Jurado, J., Morillas, A., Moya, F. Plaza, F., Serra, M., Tel, E., Vargas-Yañez, M., Vicente, L., Zunino, P., Alvarez, M., and Bange, H.: Implementing a multidisciplinary monitoring system in the Spanish Mediterranean, in: 39th CIESM, CIESM The Mediterranean Science Commission, The Mediterranean Science Commission, Venice, Italy, 10-14 May, available at: http://www.ciesm.org/online/archives/ abstracts/pdf/39/PG_0086.pdf (last access: 13 October 2015), 2010.

Aparicio-González, A., López-Jurado, J. L., Balbín, R., Alonso, J. C., Amengual, B., Jansá, J., García, M. C., Moyá, F., Santiago, R., Serra, M., and Vargas-Yáñez, M.: IBAMar Database: Four Decades of Sampling on the Western Mediterranean Sea. Data Science Journal, 13, 172-191. 2015.

Bode, A., Acuña, J. L., González-Quirós, R., Miranda, A., and Rodríguez, M. C.: RADIALES time series: 25 years building monitoring and analytical capacities in the Iberian shelf, in: 2nd International Ocean Research Conference, One Planet one ocean, Barcelona, Spain, 17-21 November 2014, p 112, , 2014.

Carbonell, A., Tor, A., Álvarez-Berastegui, D., Vélez-Velchí, P., Dos Santos, A., Babín, R., and Alemany, F.: Environmental driving forces determining the epipelagic Decapod larval community distribution in the Balearic Sea (Western Mediterranean), Crustaceana, 6, 686-714, 2014.

Company, J. B., Puig, P., Sardà, F., Palanques, A., Latasa, M., and Scharek, R.: Climate Influence on Deep Sea Populations, PLoS ONE, Public Library of Science, 3, e1431, 2008. doi:10.1371/journal.pone.0001431

Freeland, H. J., Roemmich, D., Garzoli, S. L., Le Traon, P.Y., Ravichandran, M., Riser, S., Thierry, V., Wijffels, S., Belbéoch, M., Gould, J., Grant, F., Ignazewski, M., King, B., Klein,
B., Mork, K. A., Owens, B., Pouliquen, S., Sterl, A., Suga T., Suk, M., Sutton, P., Troisi, A., Vélez-Belchi, P. J., and Jianping, X.: Argo-a decade of progress, in: OceanObs 09: Sustained Ocean Observations and Information for Society, Vol. 2, Venice, Italy, 21-25 September 2009, avalaible at: http://www. oceanobs09.net/proceedings/cwp/cwp32/index.php (last access: 13 October 2015), 2010.

Garcia, M. J., Tel, E., and Molinero, J.: Sea-level variations on the north and northwest coasts of Spain, ICES J. Mar. Sci., 69, 720 727, doi:10.1093/icesjms/fss058, 2012.

Garcia-Garcia, L., Ruiz-Villarreal, M., and Bernal, M.: A biophysical model for simulating early life stages of sardine in the Iberian Atlantic stock, Fish. Res.173(39), 250-272, doi:10.1016/j.fishres.2015.10.002.

Garcia-Soto, C.: Prestige oil spill and Navidad flow, J. Mar. Biol. Assoc. UK, 84, 297-300, 2004.

Hernandez-Guerra, A., Joyce, T. M., Fraile-Nuez, E., and VelezBelchi, P.: Using Argo data to investigate the Meridional Overturning Circulation in the North Atlantic, Deep-Sea Res. Pt. I, 57, 29-36, doi:10.1016/j.dsr.2009.10.003, 2010.

Hidalgo, M., Reglero, P., Álvarez-Berastegui, D., Pérez-Torres, A., Álvarez, I., Rodríguez, J. M., Carbonel, A., Zaragoza, N., Tor, A., Goñi, R., Mallol, S., Babín, R., and Alemany, F.: Hydrographic and biological components of seascape structure the meroplankton community in a frontal system, Marine Ecology Progress Series, 505, 65-80, 2014.

Lopez-Jurado, J., Gonzalez-Pola, C., and Velez-Belchi, P.: Observation of an abrupt disruption of the long-term warming trend at the Balearic Sea, western Mediterranean Sea, in summer 2005, Geophys. Res. Lett., 32, 124606, doi:10.1029/2005GL024430, 2005.

López-Jurado, J. L., Balbín, R., Amengual, B., Aparicio-González, A., Fernández de Puelles, M. L., García-Martínez, M. C., Gazá, M., Jansá, J., Morillas-Kieffer, A., Moyá, F., Santiago, R., Serra, M., Vargas-Yáñez, M., and Vicente, L.: The RADMED monitoring programme as a tool for MSFD implementation: towards an ecosystem-based approach, Ocean Sci., 11, 897-908, doi:10.5194/os-11-897-2015, 2015.

Monteiro, C. E., Cardeira, S., Cravo, A., Bebianno, M. J., Sanchez, R. F., and Relvas, P.: Influence of an upwelling filament on the distribution of labile fraction of dissolved $\mathrm{Zn}, \mathrm{Cd}$ and $\mathrm{Pb}$ off Cape Sao Vicente, SW Iberia, Cont. Shelf. Res., 94, 28-41, doi:10.1016/j.csr.2014.12.004, 2015.

Otero, P., Ruiz-Villarreal, M., and Peliz, A.: Variability of river plumes off Northwest Iberia in response to wind events, J. Marine Syst., 72, 238-255, doi:10.1016/j.jmarsys.2007.05.016, 2008.

Otero, P., Ruiz-Villarreal, M., and Peliz, A.: River plume fronts off NW Iberia from satellite observations and model data, ICES J Mar. Sci., 66, 1853-1864, doi:10.1093/icesjms/fsp156, 2009.

Parrilla, G.: Oceanografía operacional: un nuevo reto, Física de la Tierra, Servicio Publicaciones Univ. Complutense Madrid, Madrid, Spain, 167-179, available at: http://revistas.ucm.es/ index.php/FITE/article/view/FITE0101110167A/11942 (last access: 13 October 2015), 2001.

Prieto, E., González-Pola, C., Lavín, A., Sánchez, R. F., and RuizVillarreal, M.: Seasonality of intermediate waters hydrography west of the Iberian Peninsula from an $8 \mathrm{yr}$ semiannual time series of an oceanographic section, Ocean Sci., 9, 411-429, doi:10.5194/os-9-411-2013, 2013. 
Prieto, E., Gonzalez-Pola, C., Lavin, A., and Holliday, N. P.: Interannual variability of the northwestern Iberia deep ocean: response to large-scale North Atlantic forcing, J. Geophys. Res.Oceans, 120, 832-847, doi:10.1002/2014JC010436, 2015.

Puig, P., De Madron, X. D., Salat, J., Schroeder, K., Martín, J., Karageorgis, A. P., Palanques, A., Roullier, F., Lopez-Jurado, J. L., Emelianov M., and others. Thick bottom nepheloid layers in the western Mediterranean generated by deep dense shelf water cascading, Prog. Oceanogr., 111, 1-23, 2013.

Rodríguez, J. M., Álvarez, I., López-Jurado, J. L., García, A., Balbín, R., Álvarez-Berastegui, D., Torres, A. P., and Alemany, F.: Environmental forcing and the larval fish community in the Balearic region (Western Mediterranean) in early summer 2005, Deep-Sea Res., 77, 11-22, 2013.

Roemmich, D., Belbeoch, M., Velez-Belchi, P., Freeland, H., Gould, W., Grant, F., Ignaszewski, M., King, B., Klein, B., Mork, K., Owens, W., Pouliquen, S., Ravichandran, M., Riser, S., Sterl, A., Suga, T., Suk, M.-S., Sutton, P., Thierry, V., LeTraon, P.-Y., Wijffels, S., and Xu, J.: Argo: the challenge of continuing 10 years of progress, Oceanography, 22, 46-55, 2009.

Ruiz-Villarreal, M., González-Pola, C., del Rio, G. D., Lavin, A., Otero, P., Piedracoba, S., and Cabanas, J.: Oceanographic conditions in north and northwest Iberia and their influence on the Prestige Oil Spill, Mar. Pollut. Bull., 53, 220-238, 2006.

Ruiz-Villarreal, M., Garcia-Garcia, L., Cobas, M., Diaz, P.A. and Reguera, B.: Modelling the hydrodynamic conditions associated with Dinophysis blooms in Galicia (NW Spain) Harmful Algae, doi:10.1016/j.hal.2015.12.003.

Salat, J., Emelianov, M., and López-Jurado, J. L.: Atypical western Mediterranean deep water formation during winter 2005, in: Rapp. Comm. Int. Mer Medit, 38th CIESM Congress, Istanbul, Turkey, 9-13 April 2007, p. 197, available at: http://www.ciesm.org/online/archives/abstracts/pdf/38/ CIESM_Congress_2007_Istanbul_article_0197.pdf (last access: 13 October 2015), 2007.

Schroeder, K., Millot, C., Bengara, L., Ben Ismail, S., Bensi, M., Borghini, M., Budillon, G., Cardin, V., Coppola, L., Curtil, C., Drago, A., El Moumni, B., Font, J., Fuda, J. L., GarcíaLafuente, J., Gasparini, G. P., Kontoyiannis, H., Lefevre, D., Puig, P., Raimbault, P., Rougier, G., Salat, J., Sammari, C., Sánchez Garrido, J. C., Sanchez-Roman, A., Sparnocchia, S., Tamburini, C., Taupier-Letage, I., Theocharis, A., VargasYáñez, M., and Vetrano, A.: Long-term monitoring programme of the hydrological variability in the Mediterranean Sea: a first overview of the HYDROCHANGES network, Ocean Sci., 9, 301-324, doi:10.5194/os-9-301-2013, 2013.

Somavilla, R., González-Pola, C., Rodriguez, C., Josey, S., Sánchez, R., and Lavín, A.: Large changes in the hydrographic structure of the Bay of Biscay after the extreme mixing of winter 2005, J. Geophys. Res.-Oceans, 114, C01001, doi:10.1029/2008JC004974, 2009.

Somavilla, R., González-Pola, C., Lavín, A., and Rodriguez, C.: Temperature and salinity variability in the south-eastern corner of the Bay of Biscay (NE Atlantic), J. Marine Syst., 109, S105S120, 2013.

Tel, E.: Variabilidad y tendencias del nivel del mar en las costas de la península Ibérica y zonas limítrofes: su relación con parámetros meteorológicos, Tesis Doctorales, Instituto Español de Oceanografia, Universidad Salamanca, Salamanca,
Spain, available at: http://www.revistas.ieo.es/index.php/tesis_ doctorales_ieo/article/view/31 (last access: 13 October 2015), 2007.

Tel, E. and Garcia, M.: Nivel del mar en las costas españolas y su relación con el clima, Asociación Española de Climatologí a (AEC), serie A, 101-110, available at: http://www. divulgameteo.es/uploads/Nivel-mar-costas-españolas.pdf (last access: 13 October 2015), 2002.

Tel, E., Cabanas, J. M., Gonzalez, G., and Cabrero, A.: Improving the knowledge of sub-surface temperature, salinity and fluorescence variability patterns on the Southern Coast of Galicia, in: Proceedings of ICES Annual Science Conference, A Coruna, Spain, 15-19 September 2014, H1814, 2014.

Tintoré, Joaquín and Vizoso, Guillermo and Casas, Benjamín and Heslop, Emma and Pascual, Ananda and Orfila, Alejandro and Ruiz, Simón and Martínez-Ledesma, Miguel and Torner, Marc and Cusí, Simó and others: SOCIB: The Balearic Islands coastal ocean observing and forecasting system responding to science, technology and society needs. Marine Technology Society Journal, 47(1),101-117, 2013.

Valdés, L., Lavín, A., Fernández de Puelles, M. L., Varela, M., Anadon, R., Miranda, A., Camiñas, J., and Mas, J.: Spanish Ocean Observation System, IEO Core Project: studies on time series of oceanographic data, Elsev. Oceanogr. Serie., 66, 99105, 2002.

Vargas-Yanez, M., Moya, F., García-Martínez, M., Rey, J., González, M., and Zunino, P.: Relationships between Octopus vulgaris landings and environmental factors in the northern Alboran Sea (southwestern Mediterranean), Fish. Res., 99, 159-167, 2009.

Vargas-Yáñez, M., Moya, F., García-Martínez, M., Tel, E., Zunino, P., Plaza, F., Salat, J., Pascual, J., López-Jurado, J. L., and Serra, M.: Climate change in the western Mediterranean Sea 1900-2008, J. Marine Syst., 82, 171-176, 2010.

Vargas-Yáñez, M., Zunino, P., Schroeder, K., López-Jurado, J., Plaza, F., Serra, M., Castro, C., García-Martínez, M., Moya, F., and Salat, J.: Extreme western intermediate water formation in winter 2010, J. Marine Syst., 105, 52-59, 2012.

Vélez-Belchí, P., Hernández-Guerra, A., Fraile-Nuez, E., and Benítez-Barrios, V.: Changes in temperature and salinity tendencies of the upper subtropical North Atlantic ocean at $24.5^{\circ} \mathrm{N}$, J. Phys. Oceanogr., 40, 2546-2555, 2010.

Velez-Belchi, P., Hernandez-Guerra, A., Barrera, C., FraileNuez, E., Barrera, A., Llinas, O., Benitez-Barrios, V. M., Dominguez, F., Alonso-Gonzalez, I., Gonzalez-Davila, M., Santana-Casiano, M., Hernandez-Brito, J. J., Presas-Navarro, C., Aristegui-Ruiz, J., Comas-Rodriguez, I., Garijo-Lopez, J. C., Hernandez-Leon, S., Perez-Hernandez, M. D., RodriguezSantana, A., and Sosa-Trejo, D.: Monitoring the oceanic waters of the Canary Islands: the deep hydrographic section of the Canaries, in: Proceedings of IV Congress of Marine Sciences, Las Palmas de Gran Canaria, Spain, 11-13 June 2014, p. 393, available at: http://www.repositorio.ieo.es/e-ieo/bitstream/handle/ 10508/2649/PosterRaprocan.pdf?sequence=1\&isAllowed=y (last access: 13 October 2015), 2014.

Velez-Belchi, P., Gonzalez-Carballo, M., Perez-Hernandez, M. D., and Hernandez-Guerra, A.: Open ocean temperature and salinity trends in the Canary Current Large Marine Ecosystem, chap., in: Oceanographic and Biological Features in the Canary Current 
Large Marine Ecosystem, no. 115 in IOC Technical Series, edited by: Valdes, J. L. and Deniz-Gonzalez, I., IOC-UNESCO, Paris, France, 299-308, 2015.

Viloria, A.: Atlas Costero de Temperatura y Salinidad Subsuperficial en el Cantabrico, Master's thesis, Univ. Vigo, Vigo, Spain, 2012.

Viloria, A., Tel, E., Gonzalez-Pola, C., Merino, A., Reguera, I., Rodriguez, C., and Lavin, A.: 10 years of TSG records on the Cantabrian Coast, in: Proceeding of 7th PortugueseSpanish Assembly of Geodesy and Geophysics, Sociedad de Ciencias Aranzadi, San Sebastian, Spain, 23-28 June 2015, edited by: Zurutuza, J., 383-388, available at: http://www.aranzadi-zientziak.org/fileadmin/webs/7AHPGG/ docs/PDFs/Proceedings_7AHPGG.pdf (last access: 13 October 2015), 2012. 